\title{
Influence of Sea Weeds Extracts on the Growth, Quality and Productivity of Sesame (Sesamum indicum) in the Red and Lateritic Belt of West Bengal
}

\author{
Tanmoy Shankar ${ }^{1 *}$, G.C. Malik², M. Banerjee ${ }^{2}$ and A. Ghosh ${ }^{3}$ \\ ${ }^{1}$ Department of Agronomy, M.S. Swaminathan School of Agriculture, Centurion University Technology and Management, \\ Paralakhemundi, Odisha, India \\ ${ }^{2}$ Palli Siksha Bhavana, Visva-Bharati, Sriniketan, Birbhum, West Bengal, India \\ ${ }^{3}$ Central Salt and Marine Chemicals Research Institute, Bhavnagar, Gujarat, India
}

*Corresponding author: tanmoy.shankar125@gmail.com

Received: $11-01-2020$

Revised: 21-04-2020

Accepted: 27-05-2020

\begin{abstract}
An experiment was carried out during pre-kharif season of 2012 at Agricultural farm of Palli Siksha Bhavana, Visva-Bharati, Sriniketan, West Bengal. The experiment consisted of thirteen treatment combinations comprising of four concentrations of liquid extracts of two different sea weed species namely Kappaphycus $(\mathrm{K})$ and Gracilaria $(\mathrm{G})$ combined different levels of fertilizer which were replicated thrice and was laid out in complete randomized block design (CRBD). The Recommended dose of fertilizer (RDF) was 80:40:40 $\mathrm{kg} /$ ha of $\mathrm{N}: \mathrm{P}_{2} \mathrm{O}_{5}: \mathrm{K}_{2} \mathrm{O}$. The plant growth, yield and economics were significantly improved by application of the Gracilaria extract over that of the water applied plots. The application of seaweed extract along with $100 \%$ recommended dose through fertilizers also paid higher gross and net returns, return per rupees invested from summer sesame cultivation. So, use of seaweed extract proved beneficial in terms of improved growth, quality and economics of summer sesame cultivation in red and lateritic soil of West Bengal.
\end{abstract}

Keywords: Gracilaria, Kappaphycus, sea weed extracts, Sesame

Sesame (Sesamum indicum L.) commonly known as sesame or til or gingelly belongs to the family Pedaliaceae. This is regarded to be the oldest oilyielding crop known to man. Sesame occupies well over 32.5 per cent of total acreage and contributes about 21.3 per cent of total output of the world. In India, sesame is grown on an area of 15.85 lakh hectares with an annual production of 5.34 lakh tonnes. The average yield of sesame in India is very low that is $356 \mathrm{~kg}$ per ha (Anon. 2010-11). It is cultivated on a large area in the states of india. In Karnataka, it is grown on an area of 0.73 lakh hectares with an annual production of 0.33 lakh tones with a productivity of around $400 \mathrm{~kg}$ per ha. In India, sesame ranks third in area and production after groundnut and mustard. In West Bengal the production of sesame was 3.56 lakh tones in the year 2010-11 and sesame is one of the important oilseed crops in Indian Agriculture. The seeds are rich source of food, nutrition, edible oil and bio-medicine. Sesame oil has excellent nutritional, medicinal, cosmetic and cooking qualities for which it is known as 'the queen of oils seed'. Due to the presence of potent antioxidants, sesame seeds are called as 'the seeds of immortality'. Sesame cake

How to cite this article: Shankar, T., Malik, G.C., Banerjee, M. and Ghosh, A. (2020). Influence of Sea Weeds Extracts on the Growth, Quality and Productivity of Sesame (Sesamum indicum) in the Red and Lateritic Belt of West Bengal. International Journal of Bioresource Science, 7(1): 05-09.

Source of Support: None; Conflict of Interest: None 
or meal obtained as a by-product of the oil milling industry is rich in protein, vitamin (Niacine) and minerals (Ca and P). India ranks first in area (29\%), production (26\%) and export (40\%) of sesame in the world. The sea weed was around 434 species of red seaweeds, 194 species of brown seaweeds and 216 species of green seaweeds naturally occur in India; it was only until the beginning of the twenty-first century that the country made any concrete progress towards organized seaweed farming. Although the commercial potential of Kappaphycus alvarezii had been previously recognized and its culture technology had been perfected by the Central Salt and Marine Chemicals Research Institute (CSMCRI), culture at a commercial scale only began when PepsiCo India Holdings Ltd (PepsiCo) made its entry into the venture with a pilot-scale investment in the early 2000s. The entry of PepsiCo turned out to be decisive, acting as a catalyst to rejuvenate the industry-institutional linkages. Shah et al. (2012) reported that the concept of Self Help Groups (SHG) spearheaded by the National Bank for Agricultural and Rural Development (NABARD). Seaweed extracts have been marketed for several years as fertilizer additives and beneficial results from their use have been reported (Booth, 1965). Seaweed extract is definitely capable of promoting growth in both higher plants and prokaryotic organisms (Venkataraman and Mohan, 1994). These extracts have increased the yield of crops, seed germination, resistance to frost and fungal and insect attacks and uptake of inorganic constituents. Similar works have been reported in Potato, which is one of the most important cash crops amongst vegetables, being grown almost all over the world Pramanick et al. (2012) Shankar et al. (2015) reported the effect of seaweed liquid fertilizers obtained from Kappaphycus extract (K) and Gracilaria extract (G) on different crop .

\section{MATERIALS AND METHODS}

A field experiment was conducted at the Agricultural farm, Palli Siksha Bhavana (Institute of Agriculture), Visva Bharati, Sriniketan, during summer season of 2012. The farm is situated at $23^{\circ} 39$ North latitude and $87^{\circ} 42$ East longitudes and at an average altitude of $58.9 \mathrm{~m}$ above the mean sea level (MSL) in western part of South Bengal. This farm is located in the sub humid, subtropical belt. There were Thirteen treatments namely; $\mathrm{T}_{1}($ Control $+\mathrm{RDF}), \mathrm{T}_{2}(5 \% \mathrm{~K}+$ $100 \% \mathrm{RDF}), \mathrm{T}_{3}(7.5 \% \mathrm{~K}+100 \% \mathrm{RDF}), \mathrm{T}_{4}(10 \% \mathrm{~K}+$ $100 \%$ RDF), $T_{5}(15 \% \mathrm{~K}+100 \% \mathrm{RDF}), \mathrm{T}_{6}(5 \% \mathrm{G}+100 \%$ RDF), $T_{7}(7.5 \% \mathrm{G}+100 \% \mathrm{RDF}), \mathrm{T}_{8}(10 \% \mathrm{G}+100 \%$ RDF), $\mathrm{T}_{9}(15 \% \mathrm{G}+100 \% \mathrm{RDF}), \mathrm{T}_{10}(7.5 \% \mathrm{~K}+75 \%$ RDF), $\mathrm{T}_{11}(7.5 \% \mathrm{G}+75 \% \mathrm{RDF}), \mathrm{T}_{12}(7.5 \% \mathrm{~K}+50 \%$ $\mathrm{RDF})$ and $\mathrm{T}_{13}(7.5 \% \mathrm{G}+50 \% \mathrm{RDF})$ were designed in CRBD replicated thrice. The fertilizers were applied considering 80:40:40 kg of $\mathrm{N}: \mathrm{P}_{2} \mathrm{O}_{5}: \mathrm{K}_{2} \mathrm{O}$ ha $^{-1}$ as recommended dose other than decomposed organic manure. The sources of fertilizers were urea for N; Single super phosphate (SSP) for P and Muriate of potash (MOP) for K. Half dose of $\mathrm{N}$ and full dose of Pand $\mathrm{K}$ were applied as basal dose before sowing of seeds. The remaining half of nitrogen was applied as top dressing at 35 days after sowing i.e. at branching stage. Irrigation a light irrigation was given just after sowing (3 DAS) to facilitate germination since there was moisture shortage at the time of sowing. Thereafter, four irrigations were given to the crop at days after sowing i.e. pre-sowing, pre-flowering, flowering and capsule formation stage, respectively. Other cultural practices were taken care as and when necessary. Sap Spray the sea weed saps of Kapphaphycus and Gracilaria as per treatments were sprayed in the sesame field on 30, 40 and 50 DAS. The concentration of sap application varied from $5.0 \%, 7.5 \%, 10 \%$ and $15 \%(\mathrm{v} / \mathrm{v}$ basis) as per treatments using water @ 6001 ha $^{-1}$ in each spray. The water spray in the control plot was also done on the same days with the same amount of water. Adjuvant was mixed in the tanks before spraying. In the laboratory the oil content in sesame seed was estimated after the extraction of oil from the seeds with the help of Soxhlet's oil extraction apparatus (AOAC 1997)

\section{RESULTS AND DISCUSSION}

\section{Growth}

The data recored at harvest stage which is presented in Table 1, the maximum plant height $(112.6 \mathrm{~cm})$ was recorded in the treatment $\mathrm{T}_{9}(15 \%$ Gracilaria + $100 \%$ RDF) which gave statistically at par $\mathrm{T}_{7}(7.5 \%$ Gracilaria $+100 \%$ RDF $), \mathrm{T}_{8}(10 \%$ Gracilaria $+100 \%$ RDF), $\mathrm{T}_{4}(10 \%$ Kappaphycus $+100 \%$ RDF $), \mathrm{T}_{5}(15 \%$ Kappaphycus $+100 \%$ RDF $)$ and $\mathrm{T}_{6}(5 \%$ Gracilaria + $100 \% \mathrm{RDF})$. The highest dry matter $\left(236.6 \mathrm{~g} / \mathrm{m}^{2}\right)$ was recorded in the treatment $\mathrm{T}_{9}$ where $15 \%$ Gracilaria 
along with $100 \%$ RDF and it was statistically at par with 10\% Gracilaria along 100\% RDF and significantly higher than all other treatments. The lowest dry matter $\left(112.2 \mathrm{~g} / \mathrm{m}^{2}\right)$ production was recorded in $\mathrm{T}_{1}$ (Water $+\mathrm{RDF}$ ). Due to maximum plant height and branching directly affect in dry mater with maturity of different crops which was reported by Benjama et al. (2011 \& 2012) also woke on dry matter production, However, results of the present study were in conformity with the study of Pramanick et al. (2012). Whereas, the highest leaf area index (2.85) at 60 DAS was recorded and the treatment $T_{9}$ and $\mathrm{T}_{5}$ where $15 \%$ Gracilaria and Kappaphycus along with $100 \%$ RDF was applied which was statistically at par with 10\% Kappaphycus + 100\% RDF, 5\% Gracilaria $+100 \%$ RDF, $7.5 \%$ Gracilaria+ $100 \%$ RDF, and $10 \%$ Gracilaria $+100 \%$ RDF and significantly higher than all other treatments. The lowest leaf area index (1.72) was recorded in $T_{1}$ i.e. Water $+\mathrm{RDF}$ which was statistically at par with both $7.5 \%$ Kappaphycus and Gracilaria along with 75\% RDF and 50\% RDF respectively.

Table 1: Effect of seaweed extracts on growth of Sesame at different growth stages

\begin{tabular}{llll}
\hline Treatments & $\begin{array}{l}\text { Plant } \\
\text { height }\end{array}$ & $\begin{array}{l}\text { Dry matter } \\
\left(\mathbf{g} / \mathbf{m}^{2}\right)\end{array}$ & $\begin{array}{l}\text { Leaf Area } \\
\text { Index }\end{array}$ \\
\hline $\mathrm{T}_{1}:$ Water + RDF & 87.3 & 112.2 & 1.72 \\
$\mathrm{~T}_{2}: 5 \% \mathrm{~K}+100 \%$ RDF & 98.1 & 140.8 & 2.00 \\
$\mathrm{~T}_{3}: 7.5 \% \mathrm{~K}+100 \%$ RDF & 103.1 & 149.6 & 2.40 \\
$\mathrm{~T}_{4}: 10 \% \mathrm{~K}+100 \%$ RDF & 104.4 & 160.5 & 2.70 \\
$\mathrm{~T}_{5}: 15 \% \mathrm{~K}+100 \%$ RDF & 103.7 & 173.2 & 2.85 \\
$\mathrm{~T}_{6}: 5 \% \mathrm{G}+100 \%$ RDF & 104.2 & 180.8 & 2.33 \\
$\mathrm{~T}_{7}: 7.5 \% \mathrm{G}+100 \%$ RDF & 104.6 & 202.5 & 2.73 \\
$\mathrm{~T}_{8}: 10 \% \mathrm{G}+100 \% \mathrm{RDF}$ & 106.4 & 226.7 & 2.80 \\
$\mathrm{~T}_{9}: 15 \% \mathrm{G}+100 \%$ RDF & 112.6 & 236.6 & 2.85 \\
$\mathrm{~T}_{10}: 7.5 \% \mathrm{~K}+75 \%$ RDF & 100.9 & 136.2 & 1.90 \\
$\mathrm{~T}_{11}: 7.5 \% \mathrm{G}+75 \%$ RDF & 102.8 & 138.3 & 1.92 \\
$\mathrm{~T}_{12}: 7.5 \% \mathrm{~K}+50 \% \mathrm{RDF}$ & 101.3 & 134.4 & 1.88 \\
$\mathrm{~T}_{13}: 7.5 \% \mathrm{G}+50 \%$ RDF & 102.3 & 136.3 & 1.91 \\
\hline $\mathrm{S}$ Em( \pm$)$ & 3.1 & 7.40 & 0.09 \\
\hline $\mathrm{CD}$ at $5 \%$ & 9.1 & 21.59 & 0.26 \\
\hline $\mathrm{CV}(\%)$ & 5.3 & 7.8 & 6.8 \\
\hline
\end{tabular}

Recommended dose of fertilizer (RDF), Gracilaria (G), Kappaphycus (K).

\section{Yield}

The observation on seed yield, stick yield and harvest index of sesame were presented in Table 2.
Combined application of $100 \%$ recommended dose of fertilizer and along with 15\% Gracilaria produced the maximum yield of $1170.0 \mathrm{~kg} / \mathrm{ha}$ and it was significantly superior to all other treatments. The increased seed yield due to integrated application of seaweed extracts and inorganic sources was mainly responsible for improved growth attributes like crop growth rate during the vital period of seed filling that result in greater number of capsules per plant, seeds per capsules and higher test weight and ultimately increased seed yield over water + RDF was recorded as the lowest. Seed yield from each plot recorded at maturity of the crop was statistically analyzed. The treatment $\mathrm{T}_{1}$ having lowest Seed yield $(603.3 \mathrm{~kg} / \mathrm{ha})$ of pre-kharif sesame was due to poor growth of the crop under study. The seed yield of pre-kharif sesame increased markedly due to application of sea weed extracts over the yield obtained in water spray has been done. The maximum stick yield (2904.7 kg/ha) was recorded in $\left(\mathrm{T}_{9}\right) 15 \%$ Gracilaria $+100 \% \mathrm{RDF}$ and it was statistically at par with $\mathrm{T}_{4}:(10 \%$ Kappaphycus $+100 \%$ RDF ), $\mathrm{T}_{5}:(15 \%$ Kappaphycus $+100 \%$ RDF $), \mathrm{T}_{6}:(5 \%$ Gracilaria $+100 \%$ RDF $), \mathrm{T}_{7}:(7.5 \%$ Gracilaria $+100 \%$ RDF), $\mathrm{T}_{8}:(10 \%$ Gracilaria $+75 \%$ RDF $)$. Like seed yield, the lowest straw yield of sesame $(1817.7 \mathrm{~kg} /$ ha) was recorded in the $\left(T_{1}\right)$ Water + RDF. The result indicated that, when sea weed extract were added to higher doses of fertilizers, there was probably better availability of nutrients which might have resulted in better growth and ultimately resulted in better seed and straw yield. The harvest index did not vary significantly among the different fertility treatments under study. The water plots recorded relatively lowest harvest index. Harvest index (24.92\%) due to poor growth rate of the crop receiving no added nutrient and it was statistically at par with, $\mathrm{T}_{10}(7.5 \%$ Kappaphycus +75 \% RDF), \& $\mathrm{T}_{11}(7.5 \%$ Gracilaria + $75 \%$ RDF). The highest harvest index (28.71) was found in treatment T9 (28.71) where 15\% Gracilaria $+100 \%$ RDF was applied and it was statistically at par with $\mathrm{T}_{8}(10 \%$ Gracilaria $+100 \% \mathrm{RDF}), \mathrm{T}_{7}(7.5 \%$ Gracilaria $+100 \%$ RDF), $\mathrm{T}_{6}(5 \%$ Gracilaria $+100 \%$ RDF), $\mathrm{T}_{5}\left(15 \%\right.$ Kappaphycus $+100 \%$ RDF), $\mathrm{T}_{2}(5 \%$ Kappaphycus $+100 \%$ RDF), $\mathrm{T}_{3}(7.5 \%$ Kappaphycus $+100 \%$ RDF), $\mathrm{T}_{4}$ (10\% Kappaphycus $+100 \%$ RDF). The harvest index did not vary significantly among the different treatments because both seed and stick yield followed similar trend and respond similarly to the applied nutrients. The present findings were 
confirmed with the results obtained by Shah et al. (2012) on yield and productivity, Pramanik et al. (2012) and Shankar et al. (2015).

Table 2: Effect of seaweed extracts yield of sesame

\begin{tabular}{|c|c|c|c|}
\hline Treatments & $\begin{array}{l}\text { Seed yield } \\
\text { (kg/ha) }\end{array}$ & $\begin{array}{l}\text { Stick yield } \\
\text { (kg/ha) }\end{array}$ & $\begin{array}{l}\text { Harvest } \\
\text { index }(\%)\end{array}$ \\
\hline $\mathrm{T}_{1}:$ Water + RDF & 603.3 & 1817.7 & 24.9 \\
\hline $\mathrm{T}_{2}: 5 \% \mathrm{~K}+100 \% \mathrm{RDF}$ & 890.0 & 2380.0 & 27.2 \\
\hline $\mathrm{T}_{3}: 7.5 \% \mathrm{~K}+100 \% \mathrm{RDF}$ & 910.7 & 2390.3 & 27.5 \\
\hline $\mathrm{T}_{4}: 10 \% \mathrm{~K}+100 \% \mathrm{RDF}$ & 990.1 & 2560.0 & 27.8 \\
\hline $\mathrm{T}_{5}: 15 \% \mathrm{~K}+100 \% \mathrm{RDF}$ & 1041.3 & 2633.1 & 28.3 \\
\hline $\mathrm{T}_{6}: 5 \% \mathrm{G}+100 \% \mathrm{RDF}$ & 1040.3 & 2652.9 & 28.1 \\
\hline $\mathrm{T}_{7}: 7.5 \% \mathrm{G}+100 \% \mathrm{RDF}$ & 1060.0 & 2670.2 & 28.4 \\
\hline $\mathrm{T}_{8}: 10 \% \mathrm{G}+100 \% \mathrm{RDF}$ & 1077.4 & 2690.3 & 28.6 \\
\hline $\mathrm{T}_{9}: 15 \% \mathrm{G}+100 \% \mathrm{RDF}$ & 1197.0 & 2904.6 & 29.1 \\
\hline $\mathrm{T}_{10}: 7.5 \% \mathrm{~K}+75 \% \mathrm{RDF}$ & 855.0 & 2325.1 & 26.8 \\
\hline $\mathrm{T}_{11}: 7.5 \% \mathrm{G}+75 \% \mathrm{RDF}$ & 869.7 & 2355.0 & 26.9 \\
\hline $\mathrm{T}_{12}: 7.5 \% \mathrm{~K}+50 \% \mathrm{RDF}$ & 835.3 & 2326.6 & 26.4 \\
\hline $\mathrm{T}_{13}: 7.5 \% \mathrm{G}+50 \% \mathrm{RDF}$ & 850.0 & 2360.0 & 26.4 \\
\hline $\mathrm{S} \operatorname{Em}( \pm)$ & 39.76 & 135.0 & 0.7 \\
\hline $\mathrm{CD}$ at $5 \%$ & 116.0 & 394.3 & 2.0 \\
\hline CV (\%) & 7.3 & 9.4 & 4.4 \\
\hline
\end{tabular}

Recommended dose of fertilizer (RDF), Gracilaria (G), Kappaphycus (K).

\section{Oil content and yield}

The data of oil content and oil yield were presented in the Table 3. The oil content of pre-kharif sesame increased specifically due to application of sea weed extracts over the $\mathrm{T}_{1}$ (water+ RDF). The application of $100 \%$ recommended dose of fertilizer along with $15 \%$ Gracilaria $\left(\mathrm{T}_{9}\right)$ produced the highest oil content $(46.6 \%)$ and it was significantly superior to all other treatments but there were no significant differences in respect of oil content among them. The water + RDF was recorded the lowest oil content (44.9\%) of pre-kharif sesame due to poor growth of the crop under study. It was significantly lower than all other treatments except the treatments. According to Rathore et al. (2009) by the application of sea weed extract, its improving nutrient uptake like N, P, K and $S$, where oil content is directly effected due to sulphur and its oil yield. The lowest oil yield (271.1 $\mathrm{kg} / \mathrm{ha}$ ) of pre-kharif sesame due to poor growth of the crop under study. Combined application of $100 \%$ recommended dose of fertilizer and along with 15\% Gracilaria produced the highest oil yield of (557.6 $\mathrm{kg} / \mathrm{ha}$ ) and it was significantly superior to all other treatments and which was statistically at par with $\mathrm{T}_{7}$ $\left(7.5 \%\right.$ Gracilaria $+100 \%$ RDF) and $\mathrm{T}_{8}(10 \%$ Gracilaria $+100 \%$ RDF) respectively significantly higher than all other treatment. The water $+\operatorname{RDF}\left(\mathrm{T}_{1}\right)$ recorded the lowest oil yield of pre-kharif sesame. This might be due to Increase in biochemical properties like amino acid, and mineral some other element contents which indirectly effect on the oil content. as well as it promotes the oil yield by application of seaweed extract along with fertilizer (Sivasankari et al. 2006). Increase on yield and biochemical constituents and also similar result was reported by Kumar et al. (2012).

Table 3: Effect of seaweed extracts on quality of sesame crop

\begin{tabular}{|c|c|c|}
\hline Treatment & $\begin{array}{l}\text { Oil content } \\
(\%)\end{array}$ & $\begin{array}{l}\text { Oil yield } \\
\text { (Kg/ha) }\end{array}$ \\
\hline $\mathrm{T}_{1}:$ Water + RDF & 44.9 & 271.1 \\
\hline $\mathrm{T}_{2}: 5 \% \mathrm{~K}+100 \% \mathrm{RDF}$ & 45.0 & 400.7 \\
\hline $\mathrm{T}_{3}: 7.5 \% \mathrm{~K}+100 \% \mathrm{RDF}$ & 45.4 & 413.2 \\
\hline $\mathrm{T}_{4}: 10 \% \mathrm{~K}+100 \% \mathrm{RDF}$ & 45.9 & 454.3 \\
\hline $\mathrm{T}_{5}: 15 \% \mathrm{~K}+100 \% \mathrm{RDF}$ & 46.3 & 481.7 \\
\hline $\mathrm{T}_{6}: 5 \% \mathrm{G}+100 \% \mathrm{RDF}$ & 45.1 & 468.9 \\
\hline $\mathrm{T}_{7}: 7.5 \% \mathrm{G}+100 \% \mathrm{RDF}$ & 46.2 & 489.2 \\
\hline $\mathrm{T}_{8}: 10 \% \mathrm{G}+100 \% \mathrm{RDF}$ & 46.4 & 499.5 \\
\hline $\mathrm{T}_{9}: 15 \% \mathrm{G}+100 \% \mathrm{RDF}$ & 46.6 & 557.7 \\
\hline $\mathrm{T}_{10}: 7.5 \% \mathrm{~K}+75 \% \mathrm{RDF}$ & 45.8 & 391.6 \\
\hline $\mathrm{T}_{11}: 7.5 \% \mathrm{G}+75 \% \mathrm{RDF}$ & 46.2 & 401.7 \\
\hline $\mathrm{T}_{12}: 7.5 \% \mathrm{~K}+50 \% \mathrm{RDF}$ & 45.4 & 379.2 \\
\hline $\mathrm{T}_{13}: 7.5 \% \mathrm{G}+50 \% \mathrm{RDF}$ & 45.5 & 386.7 \\
\hline $\mathrm{S} \operatorname{Em}( \pm)$ & 2.3 & 23.5 \\
\hline $\mathrm{CD}$ at $5 \%$ & NS & 68.8 \\
\hline CV $(\%)$ & 8.9 & 9.4 \\
\hline
\end{tabular}

Recommended dose of fertilizer (RDF), Gracilaria (G), Kappaphycus (K).

\section{Economies}

The economics of the pre-kharif sesame cultivation was estimated in consultation with the available market price of various input and outputs. The gross return $(₹ / \mathrm{Ha})$, net return $(₹ / \mathrm{Ha})$, and return per rupee invested (₹/Ha) have been worked out and presented in the Table 4 . The $\mathrm{T}_{9}$ (15\% Gracilaria + $100 \% \mathrm{RDF}$ ) recorded the maximum gross return net return of sesame cultivation was ₹ 61012 and ₹ 39468 respectively and 15\% Gracilaria along 100\% RDF having highest return per rupee invested of ₹ 1.83, where both seaweed extract with different doses 
of RDF recorded highest among all the treatments which was closely followed by 1.80, 1.76 and 1.74 . The seed and biological yields of sesame increased significantly increased with the inclusion of seaweed extract and maximum benefit was recorded with the combined application of the two different sources of seaweed extract. Seaweed liquid has been found to be of great economic value in food crop production. Whereas similar result was conformity with Bai et al. (2011) and Panda et al. (2012) reported that at higher percentage of Gracilaria concentration increase yield which dircetly proportational to the economically valuable of crop.

Table 4: Effect of seaweed extracts on economics of sesame

\begin{tabular}{llll}
\hline Treatment Levels & $\begin{array}{l}\text { Gross } \\
\text { Return (₹) }\end{array}$ & $\begin{array}{l}\text { Net } \\
\text { Return (₹) }\end{array}$ & $\begin{array}{l}\text { Return/₹ } \\
\text { invested }\end{array}$ \\
\hline $\mathrm{T}_{1}:$ Water + RDF & 30894 & 13310 & 0.76 \\
$\mathrm{~T}_{2}: 5 \% \mathrm{~K}+100 \% \mathrm{RDF}$ & 45452 & 26518 & 1.40 \\
$\mathrm{~T}_{3}: 7.5 \% \mathrm{~K}+100 \% \mathrm{RDF}$ & 46490 & 26906 & 1.37 \\
$\mathrm{~T}_{4}: 10 \% \mathrm{~K}+100 \% \mathrm{RDF}$ & 50531 & 30307 & 1.50 \\
$\mathrm{~T}_{5}: 15 \% \mathrm{~K}+100 \% \mathrm{RDF}$ & 53120 & 31576 & 1.47 \\
$\mathrm{~T}_{6}: 5 \% \mathrm{G}+100 \% \mathrm{RDF}$ & 53078 & 34144 & 1.80 \\
$\mathrm{~T}_{7}: 7.5 \% \mathrm{G}+100 \% \mathrm{RDF}$ & 54068 & 34485 & 1.76 \\
$\mathrm{~T}_{8}: 10 \% \mathrm{G}+100 \% \mathrm{RDF}$ & 54946 & 34858 & 1.74 \\
$\mathrm{~T}_{9}: 15 \% \mathrm{G}+100 \% \mathrm{RDF}$ & 61012 & 39468 & 1.83 \\
$\mathrm{~T}_{10}: 7.5 \% \mathrm{~K}+75 \% \mathrm{RDF}$ & 43680 & 25122 & 1.35 \\
$\mathrm{~T}_{11}: 7.5 \% \mathrm{G}+75 \% \mathrm{RDF}$ & 44426 & 25868 & 1.39 \\
$\mathrm{~T}_{12}: 7.5 \% \mathrm{~K}+50 \% \mathrm{RDF}$ & 42697 & 25165 & 1.44 \\
$\mathrm{~T}_{13}: 7.5 \% \mathrm{G}+50 \% \mathrm{RDF}$ & 43444 & 25912 & 1.48 \\
\hline $\mathrm{S} \mathrm{Em}( \pm)$ & 1901 & 982 & 0.06 \\
\hline $\mathrm{CD}$ at $5 \%$ & 5550 & 2868 & 0.19 \\
\hline CV $(\%)$ & 6.9 & 5.9 & 7.5 \\
\hline
\end{tabular}

Recommended dose of fertilizer (RDF), Gracilaria (G), Kappaphycus $(K)$.

\section{CONCLUSION}

From the above results it may be concluded that in pre-kharif sesame the seaweed extracts are effective in increasing the growth parameters, yield, economics and vis-à-vis quality of sesame.. Presence of micro-elements and plant growth regulators hormones in Kappaphycus and Gracilaria extracts is probably responsible for the increased yield and improved nutrition of sesame receiving through foliar application of the extracts. Application of seaweed extract along with $100 \%$ recommended dose of fertilizers also showed higher growth and productivity of sesame as compared to all other treatments and paid higher gross return, net returns and return per rupees invested from prekharif sesame cultivation. Use of seaweed extract particularly improved the oil content in the seeds and oil production.

\section{REFERENCES}

1. Anonymous, 2010-11. Directorate of Economics and Statistics, Department of Agriculture and Cooperation, pp. 64-65.

2. AOAC International. 1997. Official methods of analysis of AOAC international. AOAC Official Method 920.39, Fat (Crude) or Ether Extract in Animal Feed, AOAC International, Gaithersburg, MD.

3. Bai, N.R., Prakash, J.W. and Goldi, S.J. 2008. Effect of seaweed extracts (SWE) on the growth and yield of Phaseolus aureus L. Indian Hydrobiology, 11: 113-119.

4. Benjama, O. and Masniyom, P. 2011. Nutritional composition and physicochemical properties of two green seaweeds (ulva pertusa and u. Intestinalis) from the pattani bay in southern thailand. Songklanakarin Journal of Science and Technology, 33(5): 575-583.

5. Booth, E. 1965. The manurial value of seaweed. South. Africa Journal of Plant Soil, 8: 138-143.

6. Kumar, N.A.,Vanlalzarzova, B., Sridhar, S. and Baluswami, M. 2012. Effect of liquid seaweed fertilizer of Sargassum wightii Grev. On the growth and biochemical content of green gram (Vigna radiata (L.) R. Wilczek). Recent Research in Science and Technology, 4(4): 40-45.

7. Panda, D., Pramanik, K. and Nayak, B.R. 2012. Use of sea weed extracts as plant growth regulators for sustainable agriculture. International Journal of Bio-resource and Stress Management, 3(3): 404-411.

8. Pramanick, B., Brahmachari, K. and Ghosh, A. 2012. Effect of seaweed saps on growth and yield improvement of green gram: African Journal of Agricultural Research, 8(13): 1180-1186.

9. Shankar, T., Malik, G.C., Banerjee, M. and Ghosh, A. 2015. Effect of Sea Weed Extracts on the Growth, Yield Attribute and Nutrient Uptake of Sesame (Sesamum indicum L.). International Journal of Bio-resource and Stress Management, 6(3): 420-423.

10. Shah, M.T., Zodape, S.T., Chaudhary, D.R. and Karuppanan, E.J.C. 2012. Seaweed sap as an alternative liquid fertilizer for yield and quality improvement of wheat. Journal of Plant Nutrition, 36(2): 192-200.

11. Sivasankari, S., M., Chandrasekaran, K., Kannathasan and Venkatesalu, V. 2006. Effect of seaweed extracts on the growth and biochemical constituents of Vigna sinensis. Bioresource Technology, 97(14): 1745-1751.

12. Venkataraman, K. and Mohan, V.R. 1997. The effect of liquid Seaweed extracts in agriculture and horticulture: Biology of Agriculture and Horticulture, 8: 309-324. 
